\title{
HIV AND AIDS IN POLAND IN 2018*
}

\section{ZAKAŻENIA HIV I ZACHOROWANIA NA AIDS W POLSCE W 2018 ROKU*}

\author{
National Institute of Public Health - National Institute of Hygiene in Warsaw \\ Department of Epidemiology of Infectious Diseases and Surveillance \\ Narodowy Instytut Zdrowia Publicznego - Państwowy Zakład Higieny \\ Zakład Epidemiologii Chorób Zakaźnych i Nadzoru
}

\begin{abstract}
AIM. The aim of the study was to assess the epidemiological situation of newly diagnosed HIV infections and AIDS cases and death among AIDS cases in Poland in 2018 in comparison to the changes in preceding years.

MATERIALS AND METHODS. Analysis of the epidemiological situation was based on reports of newly detected HIV cases and AIDS cases and the results of the annual survey of HIV testing conducted among the laboratories throughout the country.

RESULTS. In 2018 there were 1,209 HIV cases newly diagnosed in Poland (diagnosis rate: 3.15 per 100,000), including 100 among non-Polish citizens. The frequency of newly detected HIV infections decreased by nearly $14.8 \%$ compared to the previous year and was higher by almost $6.8 \%$ compared to the median in 2012-2016 years. The total number of AIDS cases was 110 (incidence 0.29 per 100,000), and 23 people died from AIDS disease $(0.06$ per 100,000). New HIV diagnoses were reported mainly among people in age 30 to 39 years (37.8\%) and among men (86.8\%). Among cases with known transmission route, $77.0 \%$ concerned among men who had sexual contact with men (MSM). However, compared to the previous year, there was a significant decrease in the percentage of infected people in all key populations, related to higher risk of HIV infection. In addition, we observe the drop in total number of infected people in 2018 compared to the previous year. Whether these observations represent just fluctuations or a stable tendency, related to decreasing incidence in different key populations can only be assessed in the following years. The percentage of AIDS cases diagnosed at the same time with HIV diagnosis decreased by $4 \%$ percent points in comparison to 2017 (from $75.7 \%$ to $71.84 \%$ of all incident AIDS cases).

CONCLUSION. Despite the decreasing total number of new HIV diagnoses overall and among different key populations compared to the previous year, it is too early to conclude that these are the results of positive preventive measures. Still, all actions should be taken to ensure timely linkage to care, considering the growing number of infected people among foreigners residing in Poland, and to improve the low frequency of testing towards HIV in the whole population.
\end{abstract}

Key words: AIDS, HIV infection, epidemiology, Poland, 2018 year

\section{STRESZCZENIE}

CEL PRACY. Celem pracy była ocena sytuacji epidemiologicznej nowo wykrytych zakażeń HIV, zachorowań na AIDS oraz zgonów osób chorych na AIDS w Polsce w roku 2018 z uwzględnieniem zmian, jakie zaszły w latach wcześniejszych.

MATERIAŁ I METODY. Ocenę sytuacji epidemiologicznej przeprowadzono na podstawie zgłoszeń nowo wykrytych przypadków HIV/AIDS pochodzących od lekarzy i z laboratoriów oraz ankiety dotyczącej liczby badań przesiewowych w kierunku HIV wykonanych przez laboratoria na terenie całego kraju. 
WYNIKI. W 2018 r. w Polsce rozpoznano zakażenie HIV u 1209 osób (wskaźnik rozpoznań 3,15 na 100000 mieszkańców), w tym u 100 obcokrajowców. Częstość nowo wykrywanych zakażeń HIV zmalała w porównaniu z rokiem poprzednim o prawie 14,8\%, natomiast w porównaniu z medianą w latach 2012-2016 była większa o 6,8\%. Ogółem u 110 osób rozpoznano AIDS (zapadalność 0,29 na 100000 mieszkańców), a 23 osoby chore na AIDS zmarły (0,06 na 100 000). Zakażenia HIV wystąpiły głównie u osób w wieku od 30 do 39 lat (37,8\%) i mężczyzn (86,8\%). Wśród osób ze znaną drogą transmisji zakażenia, 77,0\% nowo rozpoznanych zakażeń HIV zgłoszono wśród mężczyzn utrzymujących kontakty seksualne z mężczyznami (MSM). Natomiast w porównaniu z poprzednim rokiem nastąpił znaczny spadek odsetka osób zakażonych we wszystkich populacjach kluczowych, wyszczególnionych ze względu na ryzyko zakażenia wirusem HIV. Dodatkowo obserwowany jest także spadek ogólnej liczby osób zakażonych w roku 2018 w porównaniu z rokiem poprzednim. Czy obserwowane zmiany są tylko czasowe lub czy wykazują stabilną tendencję, związaną ze spadkiem wskaźnika nowych infekcji w poszczególnych populacjach będzie można ocenić dopiero w kolejnych latach. Odsetek zachorowań na AIDS, w przypadku których zakażenie HIV wykryto równocześnie z rozpoznaniem AIDS, zmniejszył się w porównaniu z 2017 r. o prawie 4 punkty procentowe (z 75,7\% do 71,8\% wszystkich zachorowań na AIDS).

WNIOSKI. Mimo spadku liczby nowo rozpoznanych zakażeń HIV ogółem oraz w poszczególnych populacjach kluczowych w porównaniu z poprzednim rokiem, jest jeszcze zbyt wcześnie, by ocenić, czy jest to wynikiem pozytywnych działań profilaktycznych. Nadal należy podjąć wszelkie działania w zakresie szybkiego włączania osób z nowo rozpoznanym zakażeniem do opieki medycznej, z uwzględnieniem rosnącej liczby osób zakażonych cudzoziemców przebywających na terenie Polski oraz poprawić niską częstość wykonywania badań w kierunku HIV w całej populacji.

Słowa kluczowe: AIDS, zakażenie HIV, epidemiologia, Polska, rok 2018

\section{INTRODUCTION}

In the European region (31 EU countries) in 2018 year, there were 26,164 newly diagnosed HIV infections (diagnosis rate 5.6 per 100,000) (1). The highest diagnosis rate was reported in Latvia (16.9 326 HIV infections), Malta (15.3 - 73 HIV infections) and in Estonia (14.4 - 190 HIV infections), and the lowest in Slovakia (1.9 - 101 HIV infections) and in Slovenia (1.7 - 35 HIV infection). Diagnosis rate above $10 / 100,000$ inhabitants was registered in 8 countries, while Poland was among 16 countries with the lowest rate of new diagnoses i.e. below 5 (diagnosis rate for Poland was 3.2 - 1233 HIV infection). Almost 40\% of infections are registered among men who had sexual contact with men (MSM). This is the main transmission route in most countries in Western and Central Europe, according to WHO European region, while in Eastern European countries the dominant group of new infections are heterosexual persons almost $70 \%$ and injecting drug users $-22.1 \%$. Despite the decreasing global trend of new HIV diagnoses, the number of new HIV infections increase in the WHO European region, mainly in Eastern Europe.

Since the implementation of epidemiological surveillance of HIV/AIDS in Poland in 1985, by the end of 2019 HIV infection was registered in 25,457 people, 5,759 cases of AIDS and 1,429 deaths of people with AIDS. The aim of the study is to assess the epidemiological situation of HIV infections and AIDS

\section{WSTĘP}

W regionie europejskim (31 krajów UE) w 2018 roku odnotowano 26164 nowe zakażenia HIV (wskaźnik nowych rozpoznań 5,6 na 100000 mieszkańców) (1). Najwyższy wskaźnik odnotowano na Łotwie (16,9 - 326 zakażeń HIV), Malcie (15,3 - 73 zakażenia HIV) i w Estonii (14,4 - 190 zakażeń HIV), a najniższy na Słowacji $(1,9$ - 101 zakażeń HIV) oraz na Słowenii (1,7 - 35 zakażeń HIV). Wskaźnik powyżej 10/100 000 mieszkańców zarejestrowano w 8 krajach, natomiast Polska znalazła się wśród 16 państw z najniższym wskaźnikiem nowych rozpoznań tj. poniżej 5 (wskaźnik dla Polski wynosił 3,2 - 1233 zakażenia HIV). Prawie $40 \%$ zakażeń rejestrowanych jest wśród mężczyzn mających kontakty seksualne z mężczyznami (MSM). Jest to dominująca droga transmisji w większości krajów Europy Zachodniej i Środkowej wg podziału regionalnego WHO, natomiast w krajach Europy Wschodniej nadal dominującą grupą są zakażenia wśród osób heteroseksualnych - prawie $70 \%$ - oraz wśród osób przyjmujących narkotyki drogą dożylną - 22,1\%. Pomimo spadkowego globalnego trendu nowych zakażeń HIV, liczba nowych rozpoznań HIV w regionie europejskim WHO rośnie, głównie na wschodzie Europy.

Od wdrożenia nadzoru epidemiologicznego nad HIV/AIDS w Polsce w 1985 r. do końca 2019 r. zarejestrowano zakażenie HIV u 25457 osób, 3759 zachorowania na AIDS oraz 1429 zgonów osób chorych na AIDS. Celem opracowania jest ocena sytuacji epidemiologicznej zakażeń HIV i zachorowań na AIDS oraz 
and deaths of people with AIDS in 2018 in Poland compared to previous years of the HIV epidemic (2).

\section{MATERIALS AND METHODS}

The assessment of the epidemiological situation in 2018 is based on the results of the analysis of newly detected HIV infections and AIDS diagnoses, provided by doctors (ZLK-4 form) and/or laboratories (ZLB-3 form) to the State Sanitary Inspection and verified by the end of December 2019. Reported cases are classified according to the HIV and AIDS case definition for epidemiological surveillance established by the decision of the European Commission (3) of 19 March 2002 (under Decision No 2119/98/EC of the European Parliament and the European Council).

Data on the number of HIV screening tests performed in 2018 come from a voluntary survey carried out annually among laboratory managers (4). The questionnaire collects aggregate data on the characteristics of people undergoing testing e.g. gender, age group and the sites of testing. The number of deaths due to diseases caused by HIV in 2018 (ICD10 codes: B20-B24) comes from the Central Statistical Office (CSO) (5).

\section{RESULTS AND DISCUSSION}

HIV testing in 2018. In 2018, at least 1,678,597 screening tests for HIV infection among Polish citizens were conducted (Table I). The testing rate was 43 tests per 1000 inhabitants, and after excluding the candidates for blood donors, about 10 tests per 1000 inhabitants.

Number of tests performed was lower compared to 2017 year, by 3\%. Data regarding to the number of HIV tests were provided by 207 laboratories from the whole country. The frequency of detection HIV infection in lab tests among Polish citizens was 0.06 per 100 performed tests. Compared to other testing sites, the highest HIV test rates were observed among those who were detained in drug treatment centre $(2.2 \%)$ and among patients of sexually transmitted infection clinics (1.7\%).

From all laboratories, which took part in questionnaire prepared by NIPH-NIH (without testing among blood donors), 163 laboratories (78.7\%) reported the number of tests aggregated by gender. Among only those laboratories that submitted a distribution of tests by gender, tests performed among females constituted the majority compare to tests among men, respectively $70.9 \%(164,629 / 232,177)$ and $28.4 \%(65,900 / 232,177)$. Overall, $16.5 \%$ of tests among women was conducted among pregnant women $-27,133$ tests. This is an increase in the number of tests performed on pregnant zgonów osób chorych na AIDS w 2018 w Polsce w porównaniu z poprzednimi latami (2).

\section{MATERIAŁY I METODY}

Ocena sytuacji epidemiologicznej HIV w 2018 r. oparta jest na wynikach analizy zgłoszeń nowo wykrytych zakażeń HIV i zachorowań na AIDS, przekazanych przez lekarzy (formularz ZLK-4) i/lub kierowników laboratoriów (formularz ZLB-3) do Państwowej Inspekcji Sanitarnej i zweryfikowanych do końca grudnia 2019 roku. Nowo wykryte przypadki klasyfikowane są zgodnie z definicją przypadku HIV i AIDS, wykorzystywaną do celów nadzoru epidemiologicznego zgodnie z Decyzją Komisji Europejskiej z dnia 19 marca 2002 roku (3). Definicja przypadków, jednolita dla całej UE, stosowana jest w celu zgłaszania chorób zakaźnych do sieci Wspólnoty na podstawie Decyzji No 2119/98/EC Parlamentu Europejskiego i Rady Europejskiej. Dodatkowe informacje o liczbie wykonanych badań przesiewowych w kierunku zakażenia HIV w Polsce w 2018 r. oraz dodatnich wyników testów potwierdzenia pochodzą z dobrowolnej ankiety przeprowadzanej corocznie w laboratoriach, które wykonują badania w kierunku HIV (4). W ankiecie zbierane są dane zagregowane, w podziale na płeć, grupy wieku badanych osób oraz miejsce wykonania badania. Dodatkowe informacje o liczbie zgonów z powodu choroby wywoływanej przez HIV (kody ICD-10: B20 - B24) w 2018 r., pochodzą z Głównego Urzędu Statystycznego (5).

\section{WYNIKI I ICH OMÓWIENIE}

Badania przesiewowe w kierunku HIV w 2018 roku. W roku 2018 wykonano ogółem co najmniej 1678597 testów przesiewowych w kierunku zakażenia HIV obywateli polskich (Tab. I.), tj. 43 testy na 1000 mieszkańców. Po wykluczeniu testów wykonywanych rutynowo u kandydatów na dawców krwi, liczba wykonanych testów zmniejsza się do około 10 testów na 1000 mieszkańców. Liczba wykonanych testów przesiewowych w kierunku HIV była niższa o $3 \%$ w porównaniu z 2017 r. Informacje o liczbie wykonanych badań w kierunku HIV uzyskano z 207 laboratoriów, działających na terenie całego kraju. Ogółem częstość wykrywania HIV w badaniach obywateli polskich wyniosła 0,06 na 100 badań, natomiast po wykluczeniu badań wśród dawców krwi, częstość wykrywania HIV wzrosła do 0,26 ma 100 badań. Najwyższą częstość w porównaniu $\mathrm{z}$ innymi grupami odnotowano wśród osób $\mathrm{z}$ ośrodków leczenia uzależnień $(2,2 \%)$ oraz pacjentów poradni skórno-wenerologicznych $(1,7 \%)$. Spośród wszystkich laboratoriów biorących udział $\mathrm{w}$ ankiecie przygotowanej przez NIZP-PZH (poza badaniami wśród dawców krwi), $163(78,7 \%)$ podało liczbę wykonanych testów 
women by $67.6 \%$ compared to the previous year, although it should be emphasized that both during the analyzed period and earlier, some tests of pregnant women could be summarized by laboratories reporting only the total number of tests. Data regarding the age of tested individuals were provided by 96 laboratories (46.4\%). Among only those laboratories that submitted a distribution of tests by age, most of the tests were recorded in the 25-34 age group - over $41 \%$, but the frequency of positive tests was highest in age group 45-54 years ( 0.50 per 100 tests) and in age group 35-44 years $(0.29$ per 100 tests) (Tab. I). w podziale na płeć badanych osób. Wśród tylko tych laboratoriów, które przesłały rozkład badań według płci, badania wśród kobiet stanowiły większość w porównaniu z badaniami wśród mężczyzn, odpowiednio $70,9 \%(164629 / 232$ 177) i 28,4\% (65 900/232 177). W tym $16,5 \%$ badań wśród wszystkich kobiet wykonano u kobiet w czasie ciąży - 27133 testy. Jest to wzrost liczby wykonanych testów u kobiet w ciąży o $67,6 \%$ testów w porównaniu z rokiem poprzednim, choć należy podkreślić, że zarówno $\mathrm{w}$ analizowanych okresie, jak i wcześniej część badań kobiet w ciąży mogła zostać wykazana przez laboratoria raportujące jedynie ogólną liczbę badań. Dane dotyczące wieku badanych osób były dostępne w 96 laboratoriach (46,4\% ogółu). Tylko wśród tych laboratoriów, które przesłały rozkład badań według wieku, najwięcej badań odnotowano w grupie wiekowej 25-34 lata - ponad 41\%, to jednak częstość dodatnich wyników była największa w grupie wieku 45-54 lata (0,50 na 100 testów) oraz 35-44 lata ( 0,29 na 100 testów) (Tab. I).

Table I. Testing for HIV in Poland in 2018

Tabela I. Badania na obecność przeciwciał anty-HIV w Polsce w 2018 r.

\begin{tabular}{|c|c|c|c|c|}
\hline \multirow{2}{*}{\multicolumn{2}{|c|}{ Testing for HIV }} & \multicolumn{3}{|c|}{ Reported number of tests } \\
\hline & & \multirow{2}{*}{$\frac{\text { Total }}{1293424}$} & \multirow{2}{*}{$\frac{\text { HIV positive }}{36}$} & \multirow{2}{*}{$\frac{\text { Frequency* }}{0.003}$} \\
\hline Blood donations centre & Blood donors & & & \\
\hline \multirow{9}{*}{$\begin{array}{l}\text { Testing site or reason for } \\
\text { testing } \\
\text { (without blood donors) }\end{array}$} & Primary care clinic & 20638 & 6 & 0.03 \\
\hline & $\begin{array}{l}\text { Infectious diseases clinics and other } \\
\text { specialist clinics }\end{array}$ & 26607 & 41 & 0.15 \\
\hline & Sexually transmitted infection clinics & 1832 & 31 & 1.69 \\
\hline & Drug treatment centers & 90 & 2 & 2.22 \\
\hline & General hospitals & 46273 & 104 & 0.22 \\
\hline & Medical staff & 2716 & 0 & 0 \\
\hline & Pregnancy care centers & 27133 & 3 & 0.01 \\
\hline & Prisons & 810 & 2 & 0.25 \\
\hline & Other / unknown** & 259074 & 827 & 0.32 \\
\hline \multirow{3}{*}{$\begin{array}{l}\text { Gender } \\
\text { (without blood donors) }\end{array}$} & Women & 164629 & 78 & 0.05 \\
\hline & Men & 65900 & 374 & 0.57 \\
\hline & Unknown & 154644 & 564 & 0.36 \\
\hline \multirow{8}{*}{$\begin{array}{c}\text { Age } \\
\text { (without blood donors) }\end{array}$} & $15-18$ years & 1831 & 2 & 0.11 \\
\hline & 19-24 years & 16764 & 33 & 0.20 \\
\hline & $25-34$ years & 47285 & 100 & 0.21 \\
\hline & $35-44$ years & 24613 & 71 & 0.29 \\
\hline & $45-54$ years & 9720 & 49 & 0.50 \\
\hline & $55-64$ years & 6678 & 16 & 0.24 \\
\hline & $65+$ years & 7091 & 6 & 0.08 \\
\hline & Unknown & 271191 & 739 & 0.27 \\
\hline \multirow{3}{*}{ Citizenship } & Polish citizens (without blood donors) & 385173 & 1016 & 0.26 \\
\hline & Polish citizens (with blood donors) & 1678597 & 1052 & 0.06 \\
\hline & Foreigners & 2085 & 70 & 3.36 \\
\hline
\end{tabular}

*Number of positive tests with respect to number of screening tests (per 100 tests)

**tests from VCT were included in other category 
In 2018 year, 2,085 tests were conducted among non-Polish citizens residing in Poland. Compare to the previous year it is an increase by $56 \%$ among this population.

Data from laboratories supply information on the number of performed tests but not on the number of tested individuals. Data are obtained in an aggregated form, without the possibility of excluding multiple tests in one person. Thus, the number of reactive results may not correspond to the number of newly detected infections reported in routine epidemiological surveillance.

HIV infection in 2018. In 2018, HIV was diagnosed in 1,209 people (diagnosis rate was 3.15 per 100,000 ) i.e. less by 210 cases than in 2017 and more by $6.8 \%$ cases compared to the median for the years 2012-2016. Above 15\% all newly detected cases of HIV infection (182 cases) were reported with delay, already in 2019.

Compared to the 2017 year, in 2018 there was twofold increase in the number of newly detected HIV infections among foreigners staying in Poland (from 51 cases in 2017 to 100 cases in 2018). Whereas compared with the average annual number of HIV diagnoses among foreigners between 2012-2016 years this was fourfold increase. Among all cases among non-Polish citizens in 2018, HIV infection were detected among 72 men and 26 women, the gender was not reported for two cases. Among all foreigners, 21 were with known nationality, and they were mainly Ukraine citizens (15 cases). Among all foreigner's possible transmission were homosexual contact (infections among MSM) 12 cases and heterosexual contacts - 7 cases.

The voivodeship with the highest number of newly detected HIV infections was mazowieckie 199 (diagnosis rate 3.69 per 100,000 ), and with the lowest number of new HIV infections was podlaskie - 15 cases $(1.27$ per 100,000$)$. In comparison with 2017, there were less infection and the increasing in diagnosis rate was recorded in 5 voivodeships (Tab. II).

The HIV infection was most often detected in the age group between 30 and 39 years - 458 (37.8\%). 16 people infected with HIV (1.3\%) were detected in persons under 20 years of age, including one infant, one child 3 years old, one 14 years old and 13 people in age 18-19 years (Tab. III). HIV infection concern mainly men: 1,049 cases $(86.8 \%$ of the total). There were 150 HIV infections diagnosed among women $(12.4 \%)$. Ratio among men to women was $7: 1$. The highest percentage of HIV infections among women was in kujawsko-pomorskie voivodeship (25.8\%) and the lowest was in mazowieckie (8.5\%). No cases were registered among women in podlaskie and świętokrzyskie voivodeship.
W roku 2018 wykonano także 2085 testów u osób będących obywatelami innego kraju, ale przebywającymi na terenie Polski. W porównaniu z rokiem poprzednim jest to wzrost liczby badań w tej grupie o ponad $56 \%$.

Należy jednak pamiętać, że dane dotyczące liczby wykonanych badań przesiewowych w Polsce dotyczą liczby wykonanych testów. Są to więc dane zagregowane i nie można wykluczyć duplikatów, co powoduje, że liczba zakażonych w każdej z grup może nie do końca odpowiadać liczbie nowo wykrytych zakażeń zgłoszonych $w$ rutynowym nadzorze.

Zakażenia HIV w 2018 roku. Ogółem w 2018 r. rozpoznano zakażenie HIV u 1209 osób (3,15 na 100000 mieszkańców), tj. o 210 przypadków mniej niż w roku 2017, oraz o 6,8\% więcej niż wyniosła mediana za lata 2012-2016. Ponad 15\% nowo wykrytych przypadków zakażenia HIV (182 przypadki) zostało zgłoszonych z opóźnieniem, dopiero w 2019 roku.

W porównaniu z 2017 r. w 2018 r. nastąpił dwukrotny wzrost liczby nowych rozpoznan HIV dotyczących obywateli innych krajów przebywających na terenie Polski (z 51 przypadków w 2017 do 100 przypadków w roku 2018). Natomiast w porównaniu ze średnią roczną liczbą rozpoznań zakażeń wśród imigrantów z lat 2012-2016 wzrost był prawie czterokrotny. W 2018 r. w tej populacji zakażenie HIV wykryto u 72 mężczyzn i 26 kobiet, w przypadku dwóch osób brak jest informacji na temat płci zakażonych osób. Wśród wszystkich cudzoziemców, dla 21 podano obywatelstwo, najczęściej byli to obywatele Ukrainy (15 przypadków). Wśród wszystkich zarejestrowanych obcokrajowców do zakażenia doszło głównie w wyniku kontaktów seksualnych z osobą tej samej płci (zakażenia wśród MSM) 12 przypadków oraz kontaktów heteroseksualnych -7 przypadków.

Najwięcej nowych osób zakażonych HIV w 2018 r. rozpoznano w województwie mazowieckim - 199 (wskaźnik rozpoznań 3,69 na 100 000), a najmniej w województwie podlaskim - 15 przypadków $(1,27$ na 100 000). W porównaniu z 2017 r. w większości województw zrejestrowano mniej zakażeń, a jedynie w 5 województwach odnotowano wzrost wskaźnika rozpoznań (Tab. II).

Najwięcej nowych zakażeń HIV wykryto u osób w grupie wieku od 30 do 39 lat $-458(37,8 \%)$. W wieku poniżej 20 lat wykryto 16 osób zakażonych HIV $(1,3 \%)$, w tym: jedno niemowlę, jedno dziecko w wieku 3 lat, 1 osoba w wieku 14 lat oraz 13 osób w wieku 18-19 lat (Tab. III). Zakażenia HIV dotyczyły głównie mężczyzn - 1049 przypadków (86,8\% ogółu), wśród kobiet wykryto 150 nowych zakażeń $(12,4 \%)$. Stosunek rozpoznań wśród mężczyzn do rozpoznań wśród kobiet wynosił 7:1. Największy odsetek zakażonych kobiet stwierdzono w woj. kujawsko-pomorskim $(25,8 \%)$, a najmniejszy w woj. mazowieckim $(8,5 \%)$. W województwie podla- 


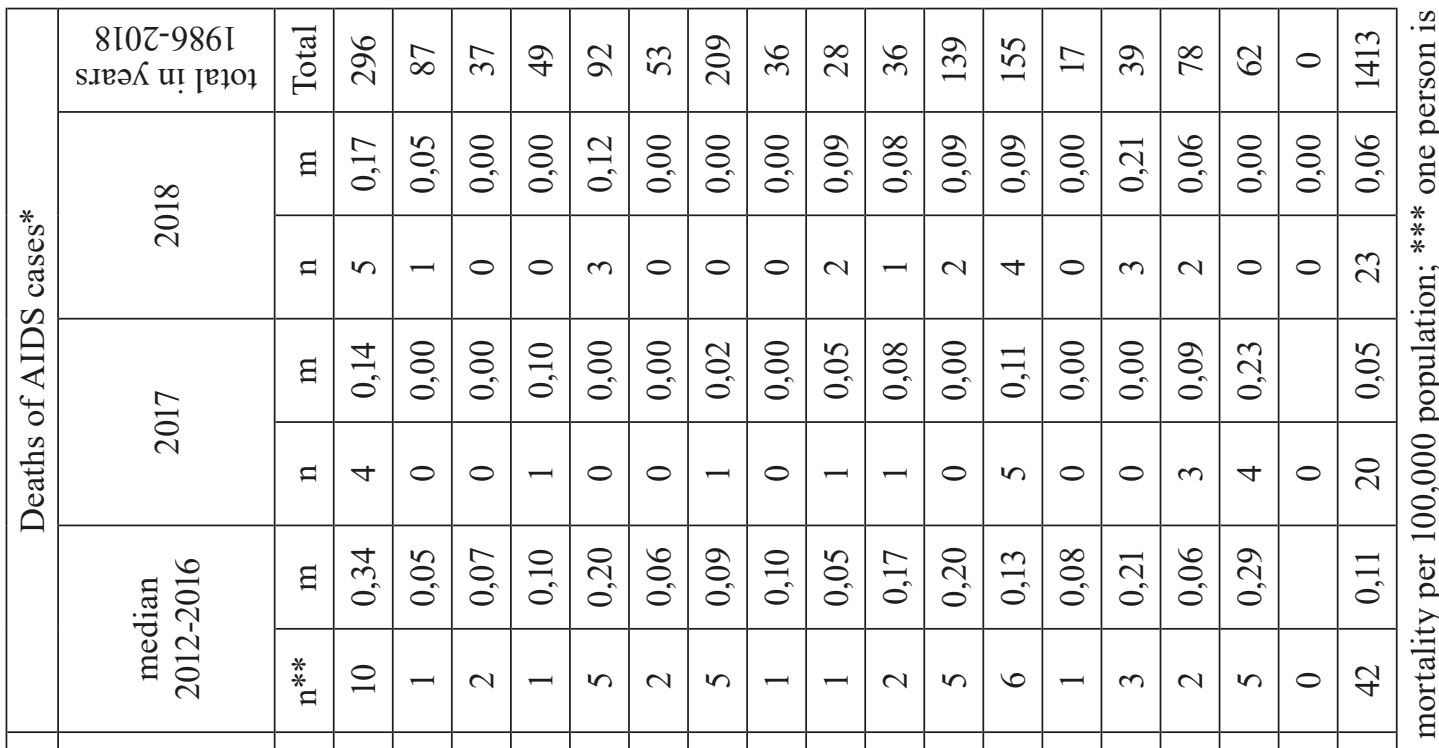

\section{0
0
0
0
0
0
3
0
3
0
0
0
1
1}

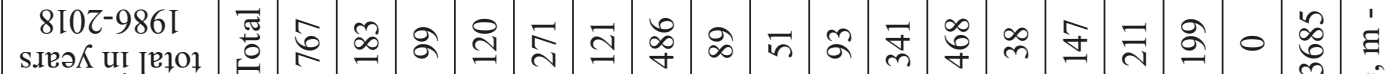

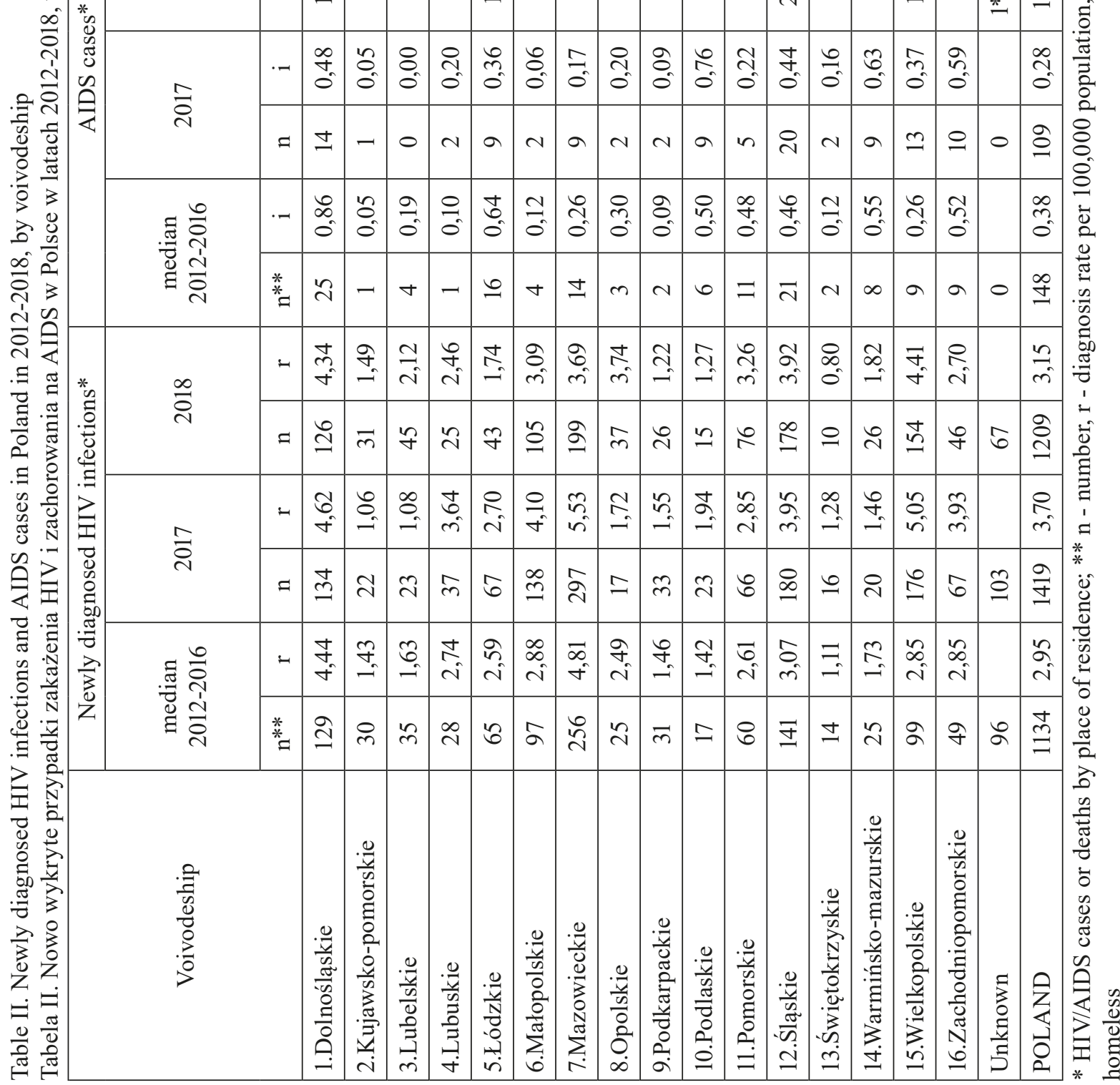

\begin{tabular}{|c|c|c|c|c|c|c|c|c|c|c|c|c|c|c|c|c|c|c|c|}
\hline & $-\neg$ & $\underset{\sigma}{\vec{\sigma}}$ & $\begin{array}{c}\stackrel{J}{J} \\
\text { ô }\end{array}$ & on & $\frac{\circ}{0}$ & $\stackrel{\circ}{+}$ & $\stackrel{8}{0}$ & $\frac{=}{0}$ & $\begin{array}{c}\text { ते } \\
\text { ô }\end{array}$ & $\frac{9}{0}$ & $\begin{array}{l}n \\
\tilde{o}\end{array}$ & $\begin{array}{l}\text { ले } \\
\text { o. }\end{array}$ & ñ & $\begin{array}{l}8 \\
0 \\
0\end{array}$ & 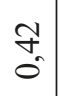 & \begin{tabular}{l}
$q$ \\
\multirow{0}{0}{}
\end{tabular} & $\bar{F}_{0}$ & & సे \\
\hline & $=$ & $\simeq$ & in & - & - & 으 & $N$ & $a$ & $N$ & $\nabla$ & $n$ & $r$ & $\stackrel{\sim}{\sim}$ & 0 & 0 & \pm & $r$ & $\underset{*}{*} \underset{*}{*}$ & $=$ \\
\hline
\end{tabular}




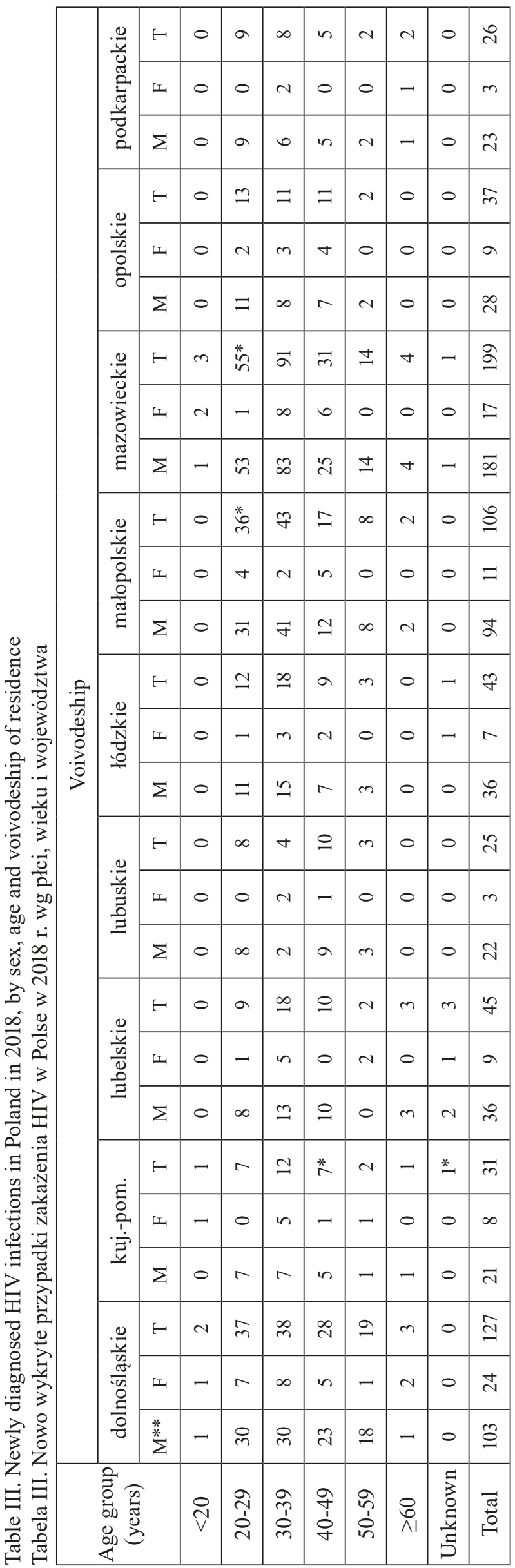

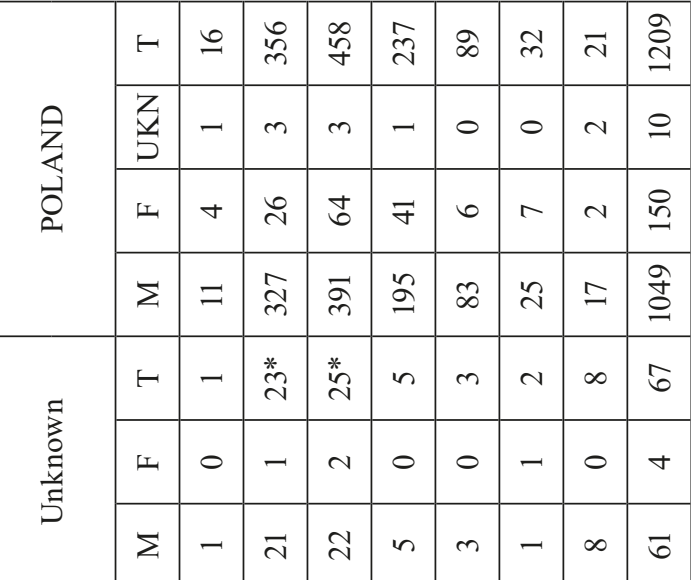

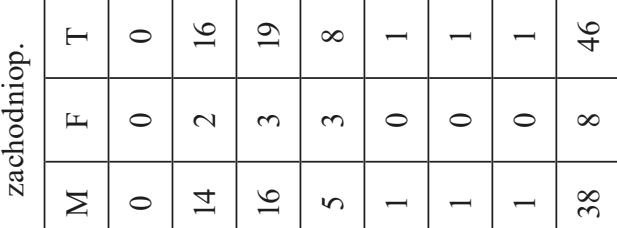

\begin{tabular}{|c|c|c|c|c|c|c|c|c|}
\hline$r$ & $\nabla$ & in & $\begin{array}{l}\text { 莒 } \\
n\end{array}$ & $\stackrel{\sim}{\sim}$ & $\simeq$ & in & $\stackrel{*}{\sim}$ & in \\
\hline LI & 0 & $N$ & $\infty$ & $\nabla$ & - & $N$ & 0 & \\
\hline & $\sigma$ & $\stackrel{\infty}{+}$ & \& & $\mathcal{N}$ & $=$ & $n$ & - & \\
\hline
\end{tabular}

\begin{tabular}{|c|c|c|c|c|c|c|c|c|}
\hline$\mapsto$ & - & $a$ & $a$ & & 0 & - & & \\
\hline
\end{tabular}

⿷匚⿱艹⿹勹亾

竞

$3=-00 \mathrm{n} 0$

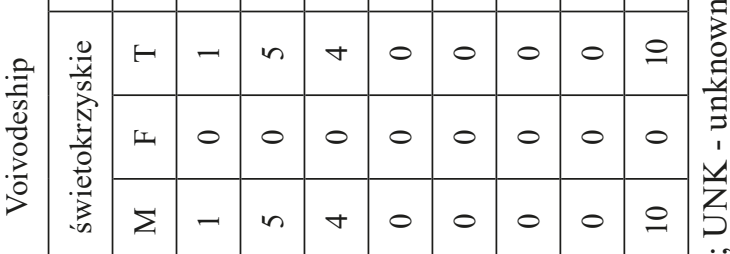

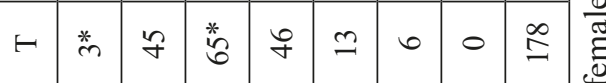

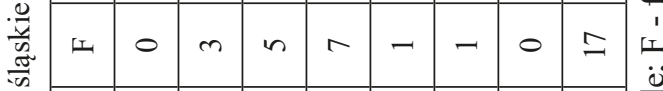

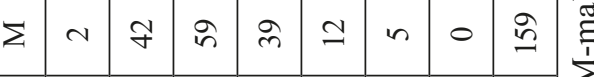

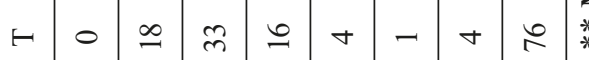

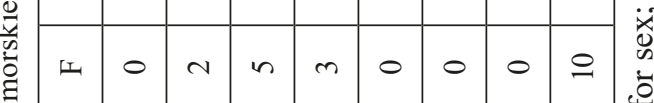

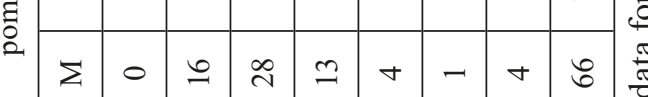

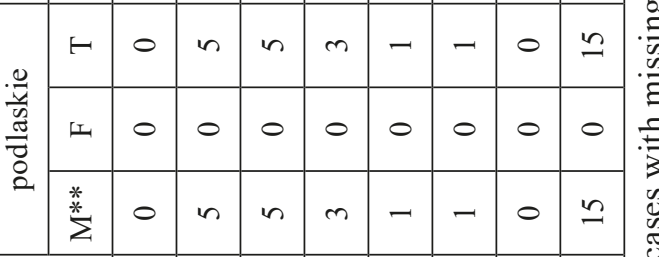

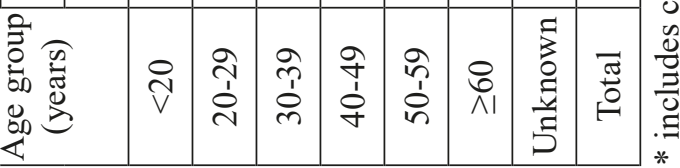


Table IV summarizes the newly detected HIV infections in different regions in Poland in 2018, according to the probable transmission route. As previously, the information on transmission route was not reported for the majority of cases $(798-66.0 \%$ of the total) and this percentage was even higher than in previous year $(872-61.5 \%$ of the total). skim oraz świętokrzyskim nie zarejestrowano żadnego przypadku zakażenia w populacji kobiet.

W tabeli IV zestawiono nowo wykryte przypadki zakażenia HIV w 2018 roku w poszczególnych województwach, według prawdopodobnej drogi zakażenia. Podobnie jak w roku ubiegłym o większości osób (798 - 66,0\% ogółu) brak jest informacji co do drogi zakażenia wirusem HIV, i ten odsetek był nawet większy niż w roku poprzednim $(872-61,5 \%$ ogółu).

Table IV. Newly diagnosed HIV infections in Poland in 2018, by voivodeship and transmission group

Tabela IV. Nowo rozpoznane przypadki zakażenia HIV w Polsce w 2018 r. wg województwa i prawdopodobnej drogi zakażenia

\begin{tabular}{|c|c|c|c|c|c|c|c|}
\hline \multirow[b]{2}{*}{ Voivodeship } & \multicolumn{6}{|c|}{ Transmission group* } & \multirow{2}{*}{$\begin{array}{c}\text { Infections } \\
\text { among } \\
\text { blood } \\
\text { donors }\end{array}$} \\
\hline & MSM & PWID & Het & $\mathrm{MtC}$ & $\mathrm{O} / \mathrm{Unk}^{* *}$ & Total & \\
\hline POLAND & 305 & 21 & 68 & 2 & 813 & 1209 & 27 \\
\hline 1.Dolnośląskie & 25 & 1 & 10 & 1 & 89 & 126 & 1 \\
\hline 2.Kujawsko-pomorskie & 2 & 0 & 0 & 1 & 28 & 31 & 1 \\
\hline 3.Lubelskie & 8 & 0 & 1 & 0 & 36 & 45 & 0 \\
\hline 4.Lubuskie & 1 & 0 & 0 & 0 & 24 & 25 & 0 \\
\hline 5.Łódzkie & 17 & 3 & 7 & 0 & 16 & 43 & 0 \\
\hline 6.Małopolskie & 12 & 0 & 1 & 0 & 92 & 105 & 3 \\
\hline 7.Mazowieckie & 115 & 2 & 19 & 0 & 63 & 199 & 5 \\
\hline 8.Opolskie & 3 & 2 & 0 & 0 & 32 & 37 & 0 \\
\hline 9.Podkarpackie & 7 & 0 & 2 & 0 & 17 & 26 & 0 \\
\hline 10.Podlaskie & 7 & 0 & 2 & 0 & 6 & 15 & 1 \\
\hline 11.Pomorskie & 25 & 1 & 8 & 0 & 42 & 76 & 0 \\
\hline 12.Śląskie & 25 & 5 & 8 & 0 & 140 & 178 & 3 \\
\hline 13.Świętokrzyskie & 3 & 0 & 2 & 0 & 5 & 10 & 2 \\
\hline 14.Warmińsko-mazurskie & 6 & 1 & 2 & 0 & 17 & 26 & 5 \\
\hline 15.Wielkopolskie & 33 & 4 & 4 & 0 & 113 & 154 & 4 \\
\hline 16.Zachodniopomorskie & 11 & 1 & 2 & 0 & 32 & 46 & 2 \\
\hline Unknown & 5 & 1 & 0 & 0 & 61 & 67 & 0 \\
\hline
\end{tabular}

* MSM - men who have sex with men, PWID - people who inject drugs, Het - heterosexual contact, MtC - child of HIV+ mother, O/Unk - other/unknown

** include 15 cases with known transmission: 13 cases - sexual contact, missing type of contact, two cases with other transmission

Among cases with known probable route of infection, the most numerous groups were MSM 305 cases $(77.0 \%$ of cases with a known transmission route) and people infected by heterosexual contact - 68 cases $(17.2 \%)$.

People who most likely acquired HIV due to the use of injection drugs accounted for less than $6 \%$ of newly-diagnosed cases with known transmission route (21 cases). Compared with previous year, the number of new HIV infections reported in all groups was smaller for e. g.: among MSM, among group infected by heterosexual contacts and in the PWID group relatively by $19.7 \%$ and $34.0 \%$ and $30.0 \%$. The
Wśród osób o znanej drodze transmisji zakażenia najliczniejszą grupę stanowią MSM - 305 osób $(77,0 \%$ przypadków o znanej drodze transmisji) oraz osoby zakażone poprzez kontakty heteroseksualne - 68 osób $(17,2 \%)$.

Osoby, które prawdopodobnie zakaziły się w wyniku stosowania środków odurzających we wstrzyknięciach - stanowiły niecałe 6\% nowo-rozpoznanych zakażeń o znanej drodze transmisji (21 osób). W porównaniu $\mathrm{z}$ rokiem poprzednim, liczba rozpoznań zmniejszyła się w każdej z grup tj. w grupie MSM, osób zakażonych poprzez kontakty heteroseksualne oraz w grupie PWID, odpowiednio o 19,7\%, 34,0\% oraz 
highest percentage of cases without transmission route (above $70 \%$ from all cases) were noticed in 9 voivodeships: dolnośląskie, kujawsko-pomorskie, lubelskie, lubuskie, małopolskie, opolskie, śląskie and wielkopolskie. The lowest percentage of missing values on transmission route, only $31.7 \%$ of cases, was registered in mazowieckie, where the infections among MSM were the dominant group, over $84.6 \%$ among cases with reported transmission route. Among HIV infected blood donors (27 cases), one was infected by heterosexual contacts and three were MSM.

Among all newly detected HIV infections reported in 2018 year, $19.3 \%$ were notified both by doctors (ZLK4 form) and by laboratories (ZLB-3 form). For $60.8 \%$ of cases, the notifications were sent by laboratories only and $19.9 \%$ were filled by doctors only.

The clinical condition at the time of HIV diagnosis was determined for $33.8 \%$ of infections diagnosed in 2018. Among these people, the majority were asymptomatic at the moment of diagnosis - 71.3\% (268 cases), while $6.1 \%$ have acute retroviral infection at the moment of HIV diagnosis, and $17.5 \%$ cases have symptoms related to immunodeficiency due to HIV infection, but without AIDS diagnosis. AIDS at the time of HIV diagnosis was indicated for $13.8 \%$ of people (52 cases).

AIDS incidence in 2018. In 2018, 110 cases of AIDS were diagnosed (incidence 0.29 per 100,000), more by one case in comparison with previous year and 8 cases more than in 2016 year, where the lowest incidence rate was noticed. Compared to the median from 2012-2016, there were 38 less cases (decrease by $25.7 \%$ ). Among total number of cases diagnosed in $2018,15.5 \%$ were registered in 2019 , which results from the process of verification in accordance with the case definition and delays in reporting of new AIDS cases.

The number of AIDS diseases remained at the same level in three voivodeships: małopolskie, mazowieckie and opolskie (incidence respectively was $0.06 ; 0.17$ and 0.20 per 100,000). The increase in the number of AIDS registered cases was observed in 7 voivodeships, including a significant increase in two voivodeships: in kujawsko-pomorskie - increase by 4 cases in relation to previous year (incidence 0.24 per 100,000) and in śląskie voivodeship - increase by 6 cases (incidence 0.57 per 100,000$)$. A decrease in incidence was recorded in six voivodeships, significant decrease was registered in three: podlaskie - decrease by 6 cases compare to 2017 (incidence 0.25 per 100,000), warmińsko-mazurskie - decrease by 3 cases (incidence 0.42 per 100,000 ) and zachodniopomorskie - decrease by 3 cases (incidence 0.41 per 100,000). One case of AIDS was diagnosed in a homeless person (Tab. II). o 30,0\%. Najwyższy odsetek przypadków zgłoszonych bez podania prawdopodobnej drogi transmisji (powyżej $70 \%$ wszystkich zgłoszeń) odnotowano w 9 województwach: dolnośląskim, kujawsko-pomorskim, lubelskim, lubuskim, małopolskim, opolskim, śląskim i wielkopolskim. Najmniejszy odsetek braku danych, tylko dla $31,7 \%$ przypadków odnotowano w województwie mazowieckim, gdzie dominującą drogą zakażenia wśród wszystkich osób ze znaną transmisją zakażenia były zakażenia w grupie MSM, ponad $84,6 \%$ przypadków.

Wśród zakażonych dawców krwi (27 przypadków), $\mathrm{u}$ jednej osoby do zakażenia doszło w wyniku kontaktów heteroseksualnych, a u 3 osób w wyniku kontaktów MSM. Wśród wszystkich zgłoszeń w roku 2018, formularz zgłoszenia zarówno od lekarza, jak i z laboratorium pozyskano w przypadku 19,3\% rozpoznań. Zgłoszenia tylko z laboratoriów otrzymano dla $60,8 \%$, a tylko zgłoszenia lekarskie - dla 19,9\%.

Stan kliniczny w momencie rozpoznania HIV określono dla 33,8\% zakażeń rozpoznanych w roku 2018. Wśród tych osób, większość zakażeń w momencie rozpoznania przebiegało bezobjawowo - 71,3\% (268 przypadków), natomiast u $6,1 \%$ zakażonych wskazano objawy ostrej infekcji retrowirusowej w momencie rozpoznania HIV, a 17,5\% zakażonych miało objawy związane $\mathrm{z}$ upośledzeniem odporności w wyniku zakażenia HIV, ale bez rozpoznania AIDS. Zachorowanie AIDS w momencie rozpoznania zakażenia HIV wskazano dla 13,8\% osób (52 przypadki).

Zachorowania AIDS w 2018 roku. W 2018 roku rozpoznano 110 zachorowań na AIDS (zapadalność 0,29 na 100000 mieszkańców), było to o 1 przypadek więcej niż w roku ubiegłym oraz o 8 przypadków więcej niż w roku 2016, w którym odnotowano najniższy wskaźnik na przestrzeni ostatnich lat. W porównaniu do mediany z lat 2012 - 2016 odnotowano spadek o 38 przypadków (o $25,7 \%$ mniej). Ze wszystkich przypadków rozpoznanych w 2018 r. 17 przypadków (15,5\%) zarejestrowano w 2019 r., co wynika z procesu weryfikacji według kryteriów definicji przypadku oraz opóźnień w raportowaniu nowych zachorowań.

W trzech województwach: małopolskim, mazowieckim oraz opolskim liczba zachorowań na AIDS pozostała taka sama jak w roku ubiegłym (zapadalność odpowiednio 0,$06 ; 0,17$ oraz 0,20 na 100000 mieszkańców). Wzrost liczby przypadków odnotowano w 7 województwach, w tym znaczący w dwóch: kujawsko-pomorskim - o 4 przypadki w stosunku do roku ubiegłego (zapadalność 0,24 na 100000 mieszkańców) oraz śląskim - o 6 przypadków (zapadalność 0,57 na 100000 mieszkańców). Spadek liczby zachorowań zanotowano w 6 województwach, w tym w trzech województwach jest on znaczący: podlaskim - o 6 przypadków w stosunku do 2017 r. (zapadalność 0,25 na 100 000), warmińsko-mazurskim - o 3 przypadki (zapadalność 0,42 
In 2018, AIDS was diagnosed in 86 men (78.2\%) and 24 women $(21.8 \%)$. The most numerous groups were MSM and people infected through heterosexual contacts, respectively 24 cases $(21.8 \%)$ and 17 cases (15.5\%). There were 10 cases $(9.1 \%)$ diagnosed among people who inject drugs. Compared to the previous year, the number of AIDS cases in the MSM group (23 cases in 2017 vs. 24 cases in 2018), and among people with heterosexual contacts (17 cases in year 2017 and 2018) remained at similar level, while among PWID the number of AIDS cases decreased ( 23 cases in 2017 vs. 10 cases in 2018).

The age distribution of people diagnosed with AIDS was as follows: the dominating group were people aged 40-49 - 38.2\% (Tab. V). The second largest group were people aged 30-39 (28.2\%). Comparing the age and gender distribution in 2018 to the distribution in 2017, a decrease in the percentage of new cases among men aged 30-39 was recorded (from $40.9 \%$ to $23.3 \%$ ), while the percentage of women in this group remained at a similar level. There was a significant increase in percentage of men among aged 40-49 years - from $28.0 \%$ to $40.7 \%$, and among women in this age group also (from $13.3 \%$ to $29.2 \%$ ). na 100 000), zachodniopomorskim - o 3 przypadki (zapadalność 0,41 na 100000 ). W jednym przypadku rozpoznano AIDS u osoby bezdomnej (Tab. II).

W 2018 r. rozpoznano AIDS u 86 mężczyzn (78,2\%) i 24 kobiet (21,8\%). Najliczniejszą grupę stanowili MSM oraz osoby podejmujące kontakty heteroseksualne, w tym odpowiednio 24 osoby $(21,8 \%)$ i 17 osób $(15,5 \%)$. Przypadków rozpoznanych u osób używających substancji psychoaktywnych w iniekcji było 10 (9,1\% ogółu). W porównaniu do roku ubiegłego liczba przypadków AIDS w grupie MSM (23 przypadki w 2017 r. vs 24 przypadki w 2018 r.) i w grupie osób utrzymujących kontakty heteroseksualne (po 17 przypadków w 2107 i 2018 roku) utrzymała się na zbliżonym poziomie, natomiast liczba zachorowań w grupie PWID spadła (23 przypadki w 2017 r. vs 10 przypadków w 2018 r.).

Rozkład wieku osób, u których rozpoznano AIDS był następujący: dominującą grupą były osoby w wieku 40-49 lat - 38,2\% zgłoszeń (Tab. V). Drugą co do wielkości grupą były osoby w wieku 30-39 lat (28,2\%). Porównując rozkład wieku i płci w roku 2018 z rozkładem w roku 2017 odnotowano spadek odsetka nowych zachorowań wśród mężczyzn w wieku 30-39 lat (z 40,9\% do $23,3 \%$ ), natomiast odsetek kobiet w tej grupie utrzymywał się na zbliżonym poziomie. Znacząco wzrósł odsetek zachorowań wśród mężczyzn w wieku 40-49 lat z $28,0 \%$ do $40,7 \%$, a także wśród kobiet będących $\mathrm{w}$ tej grupie wiekowej (z 13,3\% do 29,2\%).

Table V. AIDS cases in Poland in 2018 by sex, age* and transmission group

Tabela V. Zachorowania na AIDS w Polsce w roku 2018, wg płci, wieku* i drogi zakażenia

\begin{tabular}{|c|c|c|c|c|c|c|c|c|}
\hline \multirow{2}{*}{$\begin{array}{l}\text { Age group } \\
\text { (years) }\end{array}$} & \multicolumn{2}{|c|}{ Sex* } & \multicolumn{5}{|c|}{ Transmission group* } & \multirow{2}{*}{ Total } \\
\hline & $\mathrm{M}$ & $\mathrm{F}$ & MSM & PWID & Het & $\mathrm{MtC}$ & $\mathrm{O} / \mathrm{Unk}$ & \\
\hline$<20$ & 1 & 0 & 0 & 0 & 0 & 1 & 0 & 1 \\
\hline $20-29$ & 11 & 1 & 4 & 1 & 0 & 0 & 7 & 12 \\
\hline $30-39$ & 20 & 11 & 11 & 2 & 1 & 0 & 17 & 31 \\
\hline $40-49$ & 35 & 7 & 7 & 5 & 10 & 0 & 20 & 42 \\
\hline $50-59$ & 13 & 1 & 2 & 2 & 3 & 0 & 7 & 14 \\
\hline $60 \mathrm{i}>$ & 6 & 4 & 0 & 0 & 3 & 0 & 7 & 10 \\
\hline Total & 86 & 24 & 24 & 10 & 17 & 1 & 58 & 110 \\
\hline
\end{tabular}

* age at AIDS diagnosis; M - males, F - females; MSM - men who have sex with men, PWID - people who inject drugs, Het - heterosexual contact, MtC - mother-to-child, O/Unk - other/unknown

Comparing number of cases in 2018 with 2017, the following trends in the probable transmission route were observed in individual age groups: same sex contacts route remained at the same level across age group as in the last year; injecting drug use route dropped among age group 30-39 years (from $47.8 \%$ to $20.0 \%$ ), and an increased among age group $40-49$ years (from $30.4 \%$ to $50.0 \%$ ) and age group 50-59 years (from $8.7 \%$ to $20.0 \%$ ). The percentage of people reporting the heterosexual contacts as probable transmission
Zestawiając liczbę przypadków z roku 2018 i 2017 w poszczególnych grupach wiekowych oraz prawdopodobną drogę zakażenia zaobserwowano następujące tendencje: zakażenia w wyniku kontaktów seksualnych w poszczególnych grupach wiekowych utrzymują się na zbliżonym poziomie co w roku ubiegłym, iniekcyjne wstrzykiwanie narkotyków spadło $\mathrm{w}$ grupie wiekowej 30-39 lat (z 47,8\% do 20,0\%) oraz wzrosło w grupach wiekowych 40-49 lat (z 30,4\% do 50,0\%) oraz 50-59 lat (z 8,7\% do 20,0\%). Odsetek osób podających jako praw- 
dropped significantly among age group 30-39 years (from $47.1 \%$ to $5.9 \%$ ); but increased among age group $40-49$ years (from $23.5 \%$ to $58.8 \%$ ) and among people above 60 years old (from $0 \%$ to $17.6 \%$ ).

In 2018, at least one AIDS-related disease was determined in all 110 AIDS patients, 80 (72.7\%) were diagnosed with only one indicator disease, 28 cases $(25.5 \%)$ were diagnosed with 2 diseases, and 2 cases $(1.8 \%)$ - with three. Distribution of specific indicator diseases at the time of AIDS diagnosis is shown on Figure 1. The most frequently diagnosed AIDS indicator disease was pneumonia caused by Pneumocystis pneumoniae (28 cases), while the second most frequent was the wasting syndrome due to HIV infection (24 cases). dopodobną drogę zakażenia kontakty heteroseksualne znacznie spadł w grupie wiekowej 30-39 (z 47,1\% do $5,9 \%$ ), zaś wzrósł u osób w wieku 40-49 (z 23,5\% do $58,8 \%$ ) oraz u osób powyżej 60 r.ż. (z 0\% do 17,6\%).

W 2018 r. u wszystkich 110 chorych na AIDS określono co najmniej jedną chorobę wskaźnikową AIDS, u $80(72,7 \%)$ zdiagnozowano tylko 1 chorobę wskaźnikową, u 28 osób $(25,5 \%)$ zdiagnozowano 2 choroby, u 2 osób $(1,8 \%)$ - trzy choroby. Rozkład poszczególnych chorób wskaźnikowych w momencie rozpoznania AIDS przedstawia rycina 1 . Chorobą wskaźnikową, którą najczęściej rozpoznawano było zapalenie płuc wywołane przez Pneumocystis pneumoniae (39 przypadków), natomiast drugą co do częstości było wyniszczenie organizmu w przebiegu zakażenia HIV (18 przypadków).

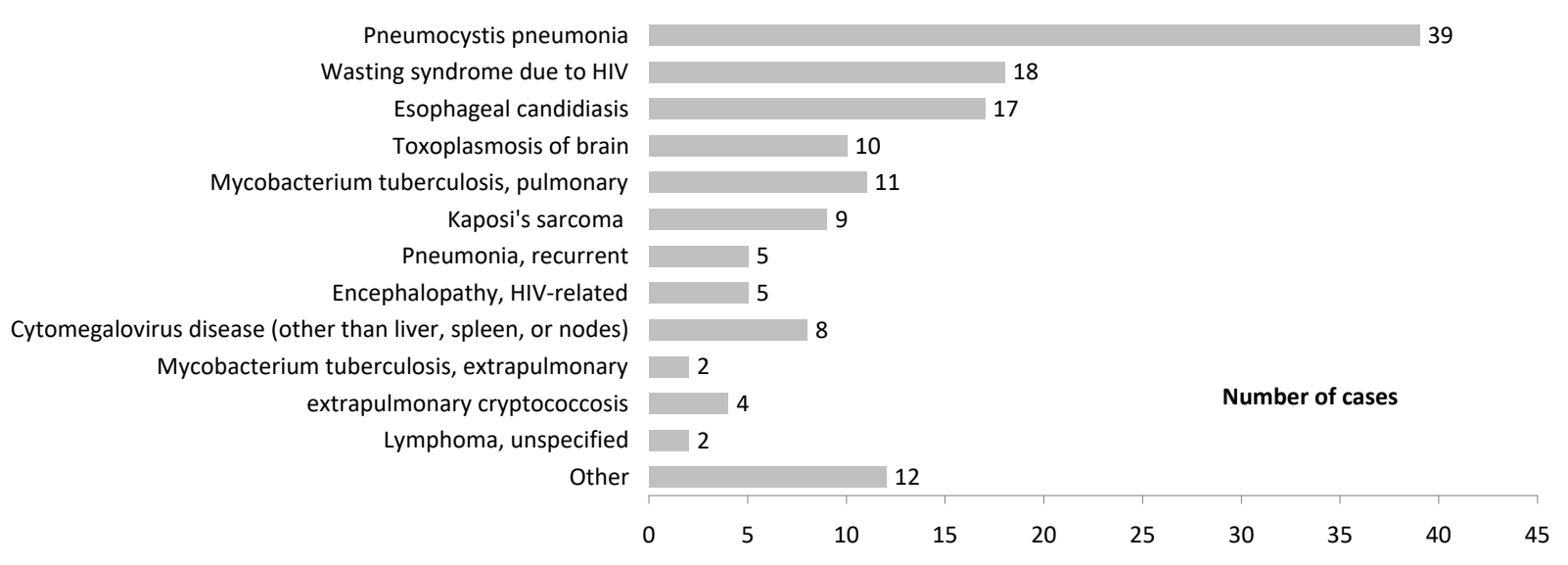

Fig.1. Indicator diseases among AIDS cases diagnosted in 2018. Number of cases

Ryc. 1. Choroby wskaźnikowe wśród osób chorych na AIDS, rozpoznanych w 2018 r. Liczba przypadków

The number of CD4 cells at the time of diagnosis of AIDS was given for 65 AIDS patients $(65.7 \%$ of the total), ranging from 1 to 466 cells per microliter (the average number was 80 cells per microliter). The value lower than 50 cells per microliter was reported in 32 cases $(49.2 \%$ among persons with reported CD4 count), in 26 cases (40.0\%) it ranged from 50 to 199 cells per microliter, and in 7 cases $(10.8 \%)$ exceeded 200 CD4 cells per microliter. Antiretroviral treatment (any attempt to treat) before the occurrence of AIDS, was administered only for 15 people (13.6\%) of all cases reported in 2018, 66 cases $(60.0 \%)$ did not undertake such treatment, and in 29 patients $(26.4 \%)$ there is no information on ART treatment before AIDS diagnosis. Concurrent diagnosis of HIV and AIDS has been reported in 79 patients diagnosed with AIDS. The percentage of late diagnoses among AIDS cases in the last five years has remained within 61$76 \%$, while the number of AIDS cases among people who have known their serostatus for 3 years or more,
Liczbę komórek CD4 w chwili rozpoznania AIDS podano dla 65 chorych na AIDS (65,7\% ogółu), wahała się ona w granicach od 1 do 466 komórek na mikrolitr (średnia liczba wynosiła 80 komórek na mikrolitr). Wartość niższa niż 50 komórek na mikrolitr była podana w 32 przypadkach $(49,2 \%$ wśród osób z podanymi wartościami CD4), w 26 przypadkach (40,0\%) mieściła się w przedziale od 50 do 199 komórek na mikrolitr, a u 7 osób (10,8\%) przekraczała 200 komórek CD4 na mikrolitr. Leczenie antyretrowirusowe (jakakolwiek próba leczenia) przed wystąpieniem AIDS było podjęte zaledwie u 15 osób (13,6\% chorych), spośród wszystkich odnotowanych zachorowań w 2018 r., a u 66 osób $(60,0 \%$ chorych) nie podjęto takiego leczenia, zaś w przypadku 29 osób (26,4\% chorych) brak jest informacji o leczeniu ART przed rozpoznaniem AIDS. W przypadku 79 chorych na AIDS rozpoznanie postawiono jednoczasowo z rozpoznaniem HIV. Odsetek późnych rozpoznań AIDS przez ostatnie 5 lat utrzymuje się w granicach 61-76\%, zaś zachorowania na AIDS wśród osób, które 
increased for the first time since 2010 compared to the previous year (Table VI). znały swój serostatus od 3 lat lub dłużej, pierwszy raz od 2010 roku wzrosły w stosunku do roku ubiegłego (Tab. VI).

Table VI. AIDS cases in Poland in 1986-2018, by the year of diagnosis and time lapse between the diagnosis of HIV infection and AIDS

Tabela VI. AIDS w latach 1986-2018, wg roku rozpoznania AIDS oraz czasu między stwierdzeniem zakażenia HIV a zachorowaniem na AIDS

\begin{tabular}{|c|c|c|c|c|c|}
\hline \multirow[b]{2}{*}{$\begin{array}{c}\text { Year of AIDS } \\
\text { diagnosis }\end{array}$} & \multicolumn{4}{|c|}{ Time lapse between detection of HIV infection and AIDS diagnosis: } & \multirow[b]{2}{*}{ Total* $^{*}$} \\
\hline & $\begin{array}{c}\text { AIDS within } 3 \\
\text { months of HIV } \\
\text { diagnosis }\end{array}$ & $\begin{array}{c}3 \text { months or } \\
\text { more after HIV } \\
\text { diagnosis, but no } \\
\text { later than } 1 \text { year }\end{array}$ & $\begin{array}{c}\text { between } 1 \text { to } 3 \\
\text { years }\end{array}$ & 3 years or later & \\
\hline $1986-1995$ & 141 & 28 & 96 & 154 & 419 \\
\hline $1996-2000$ & 204 & 25 & 88 & 316 & 633 \\
\hline $2001-2005$ & 340 & 30 & 62 & 295 & 727 \\
\hline 2006 & 83 & 6 & 15 & 60 & 164 \\
\hline 2007 & 70 & 6 & 15 & 52 & 143 \\
\hline 2008 & 89 & 7 & 11 & 62 & 169 \\
\hline 2009 & 70 & 6 & 11 & 39 & 126 \\
\hline 2010 & 87 & 6 & 15 & 65 & 173 \\
\hline 2011 & 109 & 7 & 11 & 57 & 184 \\
\hline 2012 & 87 & 3 & 12 & 55 & 157 \\
\hline 2013 & 92 & 10 & 7 & 53 & 162 \\
\hline 2014 & 107 & 3 & 4 & 33 & 147 \\
\hline 2015 & 84 & 7 & 6 & 30 & 127 \\
\hline 2016 & 62 & 7 & 14 & 18 & 101 \\
\hline 2017 & 81 & 6 & 3 & 17 & 107 \\
\hline 2018 & 79 & 3 & 3 & 25 & 110 \\
\hline Total & 1785 & 160 & 373 & 1331 & 3649 \\
\hline
\end{tabular}

* excludes 36 cases with missing date of HIV diagnosis

Deaths and mortality among AIDS cases in 2018. According to CSO data for diseases caused by HIV (code ICD-10: B20-B24), in 2018, 98 people died in Poland (mortality 0.23 per 100,000). 23 deaths of people infected with HIV were reported to the Sanitary Inspection, which occurred in 2018 (mortality 0.06 per 100,000) (Table II). Of the reported deaths, 70\% (16/23) were deaths due to HIV/AIDS. Referring this number to CSO data, it can be concluded that only $16.3 \%$ of deaths due to HIV/AIDS were reported (16/98).

According to data submitted to surveillance, no deaths were recorded in 7 voivodeships: lubelskie, lubuskie, małopolskie, mazowieckie, opolskie, świętokrzyskie and zachodniopomorskie.

In the other voivodeships, the number of deaths ranged from 1 to 5 deaths (Table II). In 2018, 14 men $(60.9 \%)$ and 9 women (39.1\%) died. In more than $65 \%$ deaths reports the probable transmission route was not indicated, while in other cases the transmission route was reported as heterosexual contacts ( 3 cases $-13.0 \%$ of all deaths), MSM and injecting drug use ( 2 deaths in
Zgony i umieralność wśród osób chorych na AIDS w 2018 roku. Według danych GUS z powodu chorób wywoływanych przez HIV (kod ICD-10: B20B24) w 2018 r. zmarło w Polsce 98 osób (umieralność 0,23 na 100000 mieszkańców). Do Inspekcji Sanitarnej zgłoszono 23 zgony osób zakażonych HIV, do których doszło w 2018 r. (umieralność 0,06 na 1000000 mieszkańców) (Tab. II). Spośród zgłoszonych zgonów prawie $70 \%(16 / 23)$ stanowiły zgony z powodu HIV/AIDS. Odnosząc tę liczbę do danych GUS można wnioskować, że zgłoszono jedynie 16,3\% zgonów z powodu HIV/AIDS $(16 / 98)$.

Według danych przekazanych do nadzoru, w 7 województwach nie odnotowano żadnego zgonu m.in. w woj.: lubelskim, lubuskim, małopolskim, mazowieckim, opolskim, świętokrzyskim oraz zachodniopomorskim. W pozostałych województwach liczba zgonów wahała się od 1 do 5 (Tab. II). W 2018 r. zmarło 14 mężczyzn $(60,9 \%)$ i 9 kobiet $(39,1 \%)$. W więcej niż $65 \%$ przypadkach zgonów nie podano prawdopodobnej drogi zakażenia, natomiast w pozostałych przypadkach 
each group $-8.7 \%$ of all deaths). In 2018 one death of a baby infected vertically was registered. The highest percentage of deaths was recorded in the age group 4049 years (39.1\% of all deaths) and in the age group 30 39 years (17.4\% of all deaths). In 2018, all deaths were reported at the same time with the AIDS notification identified at the time of death.

\section{SUMMARY}

In 2018, there was a decrease in the number of newly detected HIV infections compared to 2017 (from 1,419 to 1,209 cases) (2). This may be partially related to a slight (approximately 3\%) decrease in the number of tests. However, it should be noted that the percentage of positive results in the performed tests was also reduced.

One of the most important problems related to the HIV epidemic in Poland are the low testing rates. In 2018, similarly as in previous year, only just over 4 tests were performed per 100 inhabitants, whereas excluding tests among blood donors this would be at most $1 \%$ of population. According to the 2018 report of the National Program for the Prevention of HIV Infections and Combating AIDS, (6), there were 37,334 tests for HIV performed in VCT, and 405 people were diagnosed with HIV infection (positivity rate is $1.1 \%)$. The frequency of detecting new HIV infections among VCT clients is much higher than in the general population, e.g. almost 37 times higher than among the people testing in primary health care settings or 18 times higher than among all population tested in 2018 reported by all laboratories.

This indicates that the assumption that VCT will reach people with an increased risk of HIV infection is achieved i.e. MSM population, PWID, people with numerous sexual partners (6). One of the alternative methods of performing tests, are rapid tests which can be performed outside laboratory, and additionally they detect HIV infection 30 minutes after the test. Such tests were available in 9 from $30 \mathrm{VCT}$ in Poland. About 9,419 rapid tests were performed, which is $25.2 \%$ of all tests performed in PKD in 2018 year (6).

Rapid tests are successfully performed in other European countries. Data from the monitoring of the implementation of the Dublin Declaration referring to cooperation in the fight against HIV indicate a growing trend in the use of various forms of HIV testing, in order to increase the percentage of people testing for HIV in the general population, e.g. rapid tests performed outside the health service by qualified non-medical personnel (i.e. community-based HIV testing by lay provider) or self-testing. In 2018, the use of the above-mentioned forms of HIV testing was droga transmisji została zgłoszona jako kontakty heteroseksualne (3 zgony - 13,0\% ogółu zgonów), MSM oraz iniekcje narkotyków (po 2 zgony - 8,7\% ogółu zgonów). W 2018 r. odnotowano jeden zgon dziecka zakażonego wertykalnie. Największy odsetek zgonów odnotowano w grupie wiekowej 40-49 lat (39,1\% ogółu zgonów) oraz 30-39 lat (17,4\% ogółu zgonów). W 2018 r., wszystkie przypadki zgonów były zgłoszone jednoczasowo z rozpoznaniem zachorowania na AIDS.

\section{PODSUMOWANIE}

W 2018 r. odnotowano spadek liczby nowych zakażeń HIV w porównaniu do roku 2017 (z 1419 do 1 209 przypadków HIV) (2). Częściowo można to wiązać z niewielkim (ok. 3\%) spadkiem liczby testów. Zwraca jednak uwagę, że obniżeniu uległ również odsetek wyników dodatnich w wykonywanych badaniach.

Jednym z głównych problemów związanych z epidemią HIV w Polsce pozostaje niski odsetek testujących się osób. W roku 2018, podobnie jak w roku poprzednim, wykonano jedynie niewiele ponad 4 testy na 100 mieszkańców, a po wykluczeniu rutynowych badań wśród krwiodawców byłby to co najwyżej $1 \%$ populacji. Ze sprawozdania z realizacji Krajowego Programu Zapobiegania Zakażeniom HIV i Zwalczania AIDS (6) wynika, że w 2018 r. w PKD wykonano 37334 testy w kierunku HIV, w tym zakażenie potwierdzono u 405 osób (częstość wynosi 1,1\%). Częstość wykrywania nowych zakażeń wśród klientów PKD jest więc wielokrotnie wyższa niż w populacji generalnej, np. prawie 37 razy wyższa niż wśród badanych w podstawowej opiece zdrowotnej, czy 18 razy większa niż w całej populacji badanych osób zgłoszonych przez wszystkie laboratoria w 2018 roku. Wskazuje to na zgodne z założeniami dotarcie przez PKD do osób o zwiększonym ryzyku zakażenia HIV tj. populacji MSM, PWID, osób posiadających licznych partnerów seksualnych (6).

Jedną $\mathrm{z}$ alternatywnych metod wykonywania testów, są szybkie testy diagnostyczne, które mogą być wykonane bez konieczności wykonywania badania w laboratorium medycznym, a poza tym wykrywają zakażenie po $30 \mathrm{~min}$ od badania. Takie testy dostępne były w 9 z 30 punktów PKD w Polsce. Wykonano około 9419 szybkich testów, co stanowi 25,2\% wszystkich testów wykonanych w PKD w 2018 r. (6). Szybkie testy są $\mathrm{z}$ powodzeniem wykonywane $\mathrm{w}$ innych krajach europejskich. Dane z monitoringu implementacji deklaracji dublińskiej odwołującej się do współpracy na rzecz walki z HIV, wskazują na rosnący trend wykorzystywania różnych form testowania w kierunku HIV, dla zwiększenia odsetka osób testujących się w kierunku HIV w populacji ogólnej np. szybkie testy wykonywane poza służbą zdrowia przez wykwalifikowany personel niemedyczny ( $\mathrm{z}$ ang. community-based HIV testing by 
declared by 20/52 countries for the community-based HIV testing and 17/52 countries for the self-testing (7).

Insufficient diagnostics are still confirmed by surveillance data which indicate a stable number of late diagnoses of HIV, which both affects the deterioration of the individual prognosis for not develop AIDS disease but also increase the risk of HIV transmission in whole population by person who are undiagnosed and unaware of their infection. These results are also confirmed by studies run in HIV clinics conducted for e.g. in Lodz, where among patients diagnosed in 20092016 , over $62.9 \%$ (259 patients) were admitted already in a late stage of infection (including $68 \%$ from all who had CD4 cells below 200/ml) (8).

Among all reported 1,209 HIV infected cases in 2018, clinical notifications were received for $39.2 \%$ of all cases. Among all 110 AIDS diagnosis, only 15 cases received antiretroviral therapy before AIDS and 66 people did not undertake such treatment. All these data indicate delays in linkage-to-care of people with HIV infection, especially people who run test by themselves without medical indications. This is also confirmed by data conducted in the National AIDS Center on antiretroviral therapy in Poland (6). By the end of 2018, 11,063 people were registered on ARV treatment. The average number of new patients who starts treatment, from 2014 to 2017 (2018 data was excluded due to a much lower number of patients that may influence on epidemiological data), is about 872 patients every year. When comparing these data with the average number of newly HIV infections registered in epidemiological surveillance in the same years (about 1,287 new infections per year), about 30\% of people do not receive treatment. However, it should be noticed, that the surveillance data are burdened with an error due to the possibility of duplicate cases in correlation with anonymous tests, as well as due to delay in newly HIV infection reporting data.

Over the past years a significant percentage of case notifications suffer from missing data on probable transmission route, which limits understanding of HIV epidemiology in Poland. Despite this, based on available data both from routine surveillance and epidemiological studies conducted in Poland, there is no doubt that the problem both of HIV infection and other sexually transmitted infections, including syphilis, especially concerns the MSM population $(9,10,11)$. In addition, in last years, the number of diagnoses of HIV infection among foreigners increased. But the nationality data obtained from the surveillance are incomplete.

In 2018 on 498 reports ZLK/ZLB (41.2\% from all HIV cases) the data nationality was missing. Probably the most of these reports concern Polish citizens, but due to a twofold increase in the number of infections lay provider) czy samodzielne wykonanie testu (z ang. self-testing). W roku 2018 stosowanie $\mathrm{w} / \mathrm{w}$ form testowania w kierunku HIV deklarowało odpowiednio 20/52 kraje w przypadku community-based testing oraz 17/52 kraje w przypadku self-testing (7).

Ciągle niewystarczającą diagnostykę potwierdzają dane z nadzoru, które wskazują na utrzymującą się liczbę późnych rozpoznań, co zarówno pogarsza indywidualne rokowanie, jak i zwiększa ryzyko transmisji zakażeń HIV w populacji przez osoby niezdiagnozowane i nieświadome swojego zakażenia. Wyniki te potwierdzają również badania w klinikach HIV prowadzone m.in. w Łodzi, gdzie wśród pacjentów rozpoznanych w latach 2009-2016, ponad 62,9\% (259 pacjentów) było przyjętych już w późnym stadium zakażenia (w tym ponad $68 \%$ miało poziom komórek CD4 poniżej 200/ $\mathrm{ml})(8)$.

Wśród wszystkich zgłoszonych 1209 nowych zakażeń w 2018 r., zgłoszenie lekarskie otrzymano dla 39,2\% pacjentów. Wśród nowych rozpoznań zachorowań na AIDS tylko 15 osób na 110 miało wdrożone leczenie przed rozpoznaniem AIDS, a w przypadku 66 osób nie podjęto takiego leczenia. Wszystkie te dane mogą wskazywać na opóźnione objęcie opieką osób z rozpoznanym zakażeniem HIV, szczególnie w przypadku osób badających się z własnej inicjatywy. Potwierdzają to również dane prowadzone przez Krajowe Centrum ds. AIDS na temat osób objętych terapią antyretrowirusową w Polsce (6). Do końca roku 2018 zarejestrowano 11063 osoby na leczeniu ARV. Średnia liczba nowych pacjentów włączanych do leczenia, od roku 2014 do 2017 (rok 2018 wykluczono w powodu znacznie niższej liczby pacjentów, które mogą wpływać na niepełny obraz danych epidemiologicznych) wynosi około 872 pacjentów. W zestawieniu tych danych ze średnią liczbą nowo rozpoznawanych zakażeń rejestrowanych w nadzorze epidemiologicznym w tych samych latach (około 1287 nowych zakażeń w ciągu roku), około 30\% osób nie zostaje objęta leczeniem. Należy jednak zauważyć, że dane z nadzoru są obarczone błędem wynikającym z możliwości występowania zduplikowanych zgłoszeń rozpoznań w związku z badaniami anonimowymi, jak również $\mathrm{z}$ opóźnienia $\mathrm{w}$ raportowaniu danych o nowo rozpoznanych zakażeniach.

W ostatnich latach wśród rejestrowanych przypadków w znaczącym odsetku brakuje informacji na temat drogi zakażenia, co ogranicza ocenę sytuacji epidemiologicznej HIV w Polsce. Mimo to, opierając się na dostępnych danych zarówno z rutynowego nadzoru, jak i badań epidemiologicznych prowadzonych w Polsce, nie ulega wątpliwości, że problem zarówno zakażeń HIV, ale i innych chorób przenoszonych drogą płciową, w tym kiły dotyczy w sposób szczególny populacji $\operatorname{MSM}(9,10,11)$. 
among foreigners, such an interpretation may raise doubts. With the increasing number of infections among foreigners, special attention is needed, because some of them may not receive ARV treatment. Access to free treatment is guaranty for citizens who provided they are paid for health insurance in National Health Fund in Poland or they have voluntarily insurance, but they must have documented place of residence in Poland (12).

\section{CONCLUSIONS}

Promoting HIV testing, including improvement of the availability of rapid HIV tests, remains priority in Poland to limit HIV transmission in populations.

Linkage to care of newly detected HIV infections and increased awareness of free of charge and effective treatment should be one of the main targets in fighting with HIV epidemic in Poland.

Growing problem of migration which observed in the world and in Poland also, requires monitoring of the HIV situation among migrants coming to Poland.

\section{REFERENCES}

1. European Centre for Disease Prevention and Control/WHO Regional Office for Europe. HIV/ AIDS surveillance in Europe 2019 - 2018 data. Stockholm: ECDC; 2019

2. https://www.ecdc.europa.eu/en/publications-data/ hivaids-surveillance-europe-2019-2018-data

3. Szmulik K, Niedźwiedzka-Stadnik M, Rosińska M HIV AND AIDS IN POLAND IN 2017. Przegl Epidemiol 2019; 73(2): 179-192

4. Decyzja Komisji z dnia 19 marca 2002 r. ustanawiająca definicje przypadku w celu zgłaszania chorób zakaźnych do sieci wspólnotowej na podstawie decyzji 2119/98/WE Parlamentu Europejskiego i Rady. Dziennik Urzędowy Wspólnot Europejskich 86, 3.4.2002; 44

5. Infectious Diseases and Poisonings in Poland in 2018; Bulletins of the National Institute of Public Health and Chief Sanitary Inspectorate. Dostępne na stronie:

6. http://wwwold.pzh.gov.pl/oldpage/epimeld/2018/ Ch_2018.pdf

7. Główny Urząd Statystyczny: Bazy danych Demografia - Wyniki badań bieżących - Ruch naturalny ludności - Zgony: Tablica LN14A Zgony według przyczyn i województw rejestracji. Available on:

8. http://demografia.stat.gov.pl/bazademografia/ Tables.aspx

9. Sprawozdanie $\mathrm{z}$ realizacji Krajowego Programu Zapobiegania Zakażeniom HIV i Zwalczania AIDS w 2018 roku, opracowane przez
Dodatkowo, w ostatnich latach wzrasta również liczba nowo rozpoznanych zakażeń HIV diagnozowanych wśród obcokrajowców. Niestety dane o narodowości, pozyskiwane $\mathrm{w}$ ramach nadzoru są niepełne. W roku 2018 na 498 formularzach ZLK/ZLB (41,2\% ogółu zakażonych HIV) nie wskazano obywatelstwa. Prawdopodobnie większość tych zgłoszeń dotyczy obywateli Polski, jednakże przy dwukrotnym wzroście liczby zakażonych osób innego obywatelstwa, taka interpretacja może budzić wątpliwości. Przy wzrastającej liczbie zakażeń obcokrajowców należy szczególnie zwrócić uwagę, że część tych osób może nie być objęta leczeniem ARV. Dostęp do bezpłatnego leczenia mają obywatele innych państw pod warunkiem, że podlegają obowiązkowi ubezpieczenia zdrowotnego w Polsce albo ubezpieczają się dobrowolnie w Narodowym Funduszu Zdrowia, pod warunkiem posiadania miejsca zamieszkania w Polsce (12).

\section{WNIOSKI}

Propagowanie testowania w kierunku HIV, w tym szerszego dostępu do szybkich testów w kierunku HIV w Polsce, pozostaje zagadnieniem priorytetowym w celu ograniczania transmisji zakażeń w populacji.

Objęcie opieką medyczną nowo rozpoznanych zakażeń HIV oraz zwiększenie świadomości społeczeństwa o bezpłatnym i skutecznym leczeniu zakażeń HIV, powinno być jednym z głównych celów walki z epidemią nowych zakażeń HIV w Polsce.

Przy rosnącym problemie migracji obserwowanym na świecie, a także w Polsce, należy monitorować sytuację nowych zakażeń HIV wśród osób przybywających na teren Polski.

Krajowe Centrum do Spraw AIDS, Warszawa, 2019 r. Available on:

10. https://aids.gov.pl/krajowy_program/spr2018/

11. European Centre for Disease Prevention and Control. HIV testing: Monitoring implementation of the Dublin Declaration on partnership to fight HIV/AIDS in Europe and Central Asia: 2018 progress report. Stockholm: ECDC; 2019.

12. https://www.ecdc.europa.eu/sites/default/files/ documents/HIV-testing-dublin-declarationmonitoring-2018.pdf

13. Wójcik-Cichy K, Jabłonowska O, Piekarska A, Jabłonowska E.: The high incidence of late presenters for HIV/AIDS infection in the Lodz province, Poland in the years 2009-2016: we are still far from the UNAIDS 90\% target. AIDS Care. 2018 Dec;30(12):1538-1541

14. The Sialon II Project. Report on a Bio-behavioural Survey among MSM in 13 European cities. ISBN 978-88-98768-55-4 Cierre Grafica, 2016. Editors: 
Massimo Mirandola, Lorenzo Gios, Nigel Sherriff, Igor Toskin, Ulrich Marcus, Susanne Schink, Barbara Suligoi, Cinta Folch, Magdalena Rosińska.

15. Pastuszczak M, Bociąga-Jasik M, Sitko M, WojasPelc A.: HIV infection and sex in sex-on-premises venues are associated with a higher risk of syphilis reinfection among men who have sex with men. Postepy Dermatol Alergol. 2018 Oct;35(5):481484.

16. Serwin AB, Grochowska A, Flisiak I.: Men treated for syphilis in Białystok, Poland, 2014-2018; Przegl Epidemiol. 2019;73(3):329-335.

17. Ustawa z dnia 27 sierpnia 2004 r. o świadczeniach opieki zdrowotnej finansowanych ze środków publicznych Dz. U. z 2017 r. poz. 1938 z późn. zm. Available on:
18. https://isap.sejm.gov.pl/isap.nsf/download.xsp/ WDU20042102135/T/D20042135L.pdf

Received: 14.09.2020

Accepted to publication: 15.09 .2020

Otrzymano: 14.09.2020

Zaakceptowano do publikacji:15.09.2020

Address for correspondence:

Adres do korespondencji:

Katarzyna Szmulik-Misiurek

Narodowy Insty tut Zdrowia Publicznego - Państwowy

Zakład Higieny

Zakład Epidemiologii Chorób Zakaźnych i Nadzoru

ul. Chocimska 24, 00-791 Warszawa

tel.: + 48225421302

e-mail:kszmulik@pzh.gov.pl 